INGA KaWKa, ŁUKASZ KOZERA ${ }^{1}$

\title{
Prawne aspekty podejmowania pracy w Polsce przez cudzoziemców z państw spoza Unii Europejskiej
}

\section{Wstęp}

Od początku lat 90. XX w. utrzymuje się tendencja wzrostowa liczby cudzoziemców przebywających na terytorium Rzeczypospolitej Polskiej. Dla procesów migracyjnych kluczowe znaczenie miały przede wszystkim przemiany ustrojowe z przełomu lat 80. i 90. XX w. związane $\mathrm{z}$ otwarciem polskich granic. Cudzoziemcy przybywają do Polski m.in. w celu podjęcia zatrudnienia, poprawy standardu życia czy uzyskania ochrony międzynarodowej.

Aktualnie status prawny cudzoziemca przebywającego w Polsce regulowany jest trzema podstawowymi ustawami. Pierwszą z nich jest ustawa z dnia 12 grudnia 2013 r. o cudzoziemcach, która reguluje zasady oraz warunki ich wjazdu i pobytu tych osób na terytorium Rzeczypospolitej Polskiej $^{2}$. Drugą ustawą dotyczącą cudzoziemców jest ustawa z dnia 13 czerwca 2003 r. o udzieleniu cudzoziemcom ochrony na terytorium Rzeczypospolitej Polskiej ${ }^{3}$, trzecią natomiast ustawa z dnia 14 lipca 2006 r. o wjeździe na terytorium Rzeczpospolitej Polskiej, pobycie oraz wyjeździe z tego terytorium obywateli państw członkowskich Unii Europejskiej i członków ich rodzin ${ }^{4}$.

W polskim systemie prawnym spotkać można wiele definicji pojęcia „cudzoziemiec”. W 1982 r. Instytut Prawa Międzynarodowego przyjął definicję, zgodnie z którą „cudzoziemcami są wszyscy, którzy według obowiązującego prawa nie posiadają aktualnego obywatelstwa państwa, przez które przejeżdżają, w którym mają domicyl lub pobyt, są uchodźcami albo wjeżdżają do danego państwa za jego pełną zgodą"5. Obecnie w polskim

1 Dr hab. Inga Kawka, Katedra Prawa Europejskiego, Wydział Prawa i Administracji, Uniwersytet Jagielloński; dr Łukasz Kozera, Wydział Prawa, Wyższa Szkoła Ekonomii, Prawa i Nauk Medycznych im. prof. Edwarda Lipińskiego w Kielcach.

2 Tekst jedn.: Dz. U. z 2018 r. poz. 2094 ze zm.

3 Tekst jedn.: Dz.U. z 2018 r. poz. 1109 ze zm.

4 Tekst jedn.: Dz.U. z 2019 r. poz. 293.

5 A. Karakała, Pojęcie cudzoziemca i ogólna charakterystyka unormowań dotyczqcych jego statusu [w:] Prawo administracyjne materialne, Z. Duniewska, B. JaworskaDębska, M. Stahl (red.), Warszawa 2014, s. 67. 
ustawodawstwie przyjmuje się, że „cudzoziemcem jest każdy, kto nie posiada obywatelstwa polskiego"6.

Artykuł koncentruje się na analizie zjawiska, jakim jest napływ do Polski cudzoziemców z tzw. państw trzecich w celach zarobkowych i osiedleńczych. Przedmiotem badań są polskie ustawodawstwo oraz dane Urzędu do spraw Cudzoziemców, Głównego Urzędu Statystycznego i statystyki Ministerstwa Pracy, Rodziny i Polityki Społecznej.

\section{Cudzoziemcy na polskim rynku pracy}

\subsection{Cudzoziemcy w Polsce}

Imigracja, czyli napływ obcokrajowców do Polski, jest stosunkowo nowym zjawiskiem. Ze względu na cel i długość pobytu w Polsce można wyróżnić migracje: osiedleńcze, długookresowe, czasowe, sezonowe wahadłowe oraz przygraniczne $e^{7}$. Transformacja ustrojowa i otwarcie granic w 1989 r. spowodowało, że Polska nie tylko stała się państwem, z którego wyjeżdża się do innych krajów w poszukiwaniu pracy, ale również miejscem osiedlenia dla przybyszów z „państw trzecich”. Trudno oszacować liczbę cudzoziemców przebywających w Polsce. Zgodnie z danymi z 2011 r. pochodzącymi z ostatniego spisu powszechnego na dzień 31 marca 2011 r. w Polsce mieszkało 38,5 mln osób. Spośród wszystkich mieszkańców kraju około 98,1\% posiadało obywatelstwo polskie, natomiast prawie $1,8 \%$ urodziło się za granicą. Dla $0,1 \%$ osób kraj pochodzenia nie został ustalony ${ }^{8}$. Według danych Urzędu do Spraw Cudzoziemców na dzień 1 stycznia 2019 r. liczba osób, które posiadały ważny dokument potwierdzający prawo pobytu na terytorium Rzeczypospolitej (tzw. kartę pobytu), wynosiła 372239.

Wśród obywateli państw trzecich najliczniejszą grupę cudzoziemców posiadających kartę pobytu w Polsce w 2018 r. stanowili obywatele Ukrainy (179 154 osób), Białorusi (20 114 osób), Wietnamu (12 398), Rosji (11 976) oraz Chin (9001). Mimo pojawienia się nowych zjawisk migracyjnych Polska obecnie - tak jak podczas całej swej powojennej historii - pozostaje krajem o ujemnym saldzie migracji. Oznacza to, że więcej osób z Polski emigruje, niż do niej przyjeżdża ${ }^{9}$. Obecność zaledwie $2 \%$ cudzo-

6 Art. 3 pkt 2 ustawy o cudzoziemcach.

7 B. Samoraj, Rynek pracy a cudzoziemcy w Polsce. Garść refleksji [w:] Polityka społeczna. Badania, dydaktyka, rozwój, A. Rączaszek (red.), Katowice 2008, s. 503.

8 Dane na podstawie: Główny Urząd Statystyczny, Wyniki Narodowego Spisu Powszechnego Ludności i Mieszkań 2011. Podstawowe informacje o sytuacji demograficzno-społecznej ludności Polski oraz zasobach mieszkaniowych, https://stat.gov.pl/cps/rde/ xbcr/gus/lu_nps2011_wyniki_nsp2011_22032012.pdf (dostęp: 25.07.2018).

9 M. Szczepaniak, Cudzoziemcy w Polsce - zjawiska i charakterystyka kulturowa wybranych grup [w:] Cudzoziemcy w Polsce. Podręcznik dla funkcjonariuszy publicznych, E. Ostaszewska-Żuk (red.), Warszawa 2016, s. 14-15. 
Rysunek 1. Liczba cudzoziemców posiadających kartę pobytu w latach 2007-2018

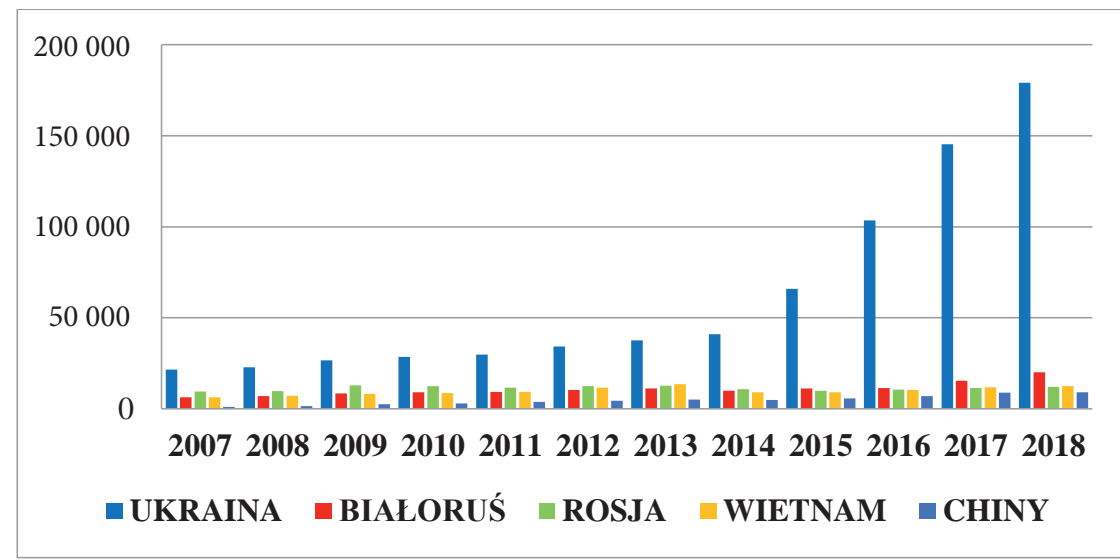

Źródło: opracowanie własne na podstawie danych Urzędu do Spraw Cudzoziemców, https://udsc.gov.pl.

ziemców na terytorium RP w skali wszystkich ewidencjonowanych obywateli jednoznacznie wskazuje, że imigracja w Polsce jest na razie zjawiskiem marginalnym. Można się jednak spodziewać, że jako kraj unijny Polska będzie stopniowo przekształcać się z państwa emigracji i tranzytu w atrakcyjne miejsce docelowe migracji ${ }^{10}$. W związku $\mathrm{z}$ tym warto zatrzymać się dłużej nad koncepcją wielokulturowości i przygotować się do wyzwań, jakie stawia przed nami obecna sytuacja gospodarcza, aby z wyprzedzeniem szukać rozwiązań problemów, które pojawiły się w innych państwach.

\subsection{Cudzoziemcy na polskim rynku pracy}

Legalne zatrudnienie stanowi zaledwie niewielki wycinek imigracji zarobkowej do Polski, natomiast rozmiary nielegalnego zatrudnienia $\mathrm{cu}-$ dzoziemców szacuje się nawet na kilkaset tysięcy osób. Najnowsza przeprowadzona przez Ministerstwo Rodziny, Pracy i Polityki Społecznej ogólnopolska prognoza sytuacji w zawodach „Barometr zawodów” wykazuje, że największym problemem przedsiębiorców w 2018 r. będzie znalezienie nowych pracowników ${ }^{11}$. Niestety, wielu młodych, wykształconych i potencjalnych pracowników polskich wyjeżdża za granicę w poszukiwaniu lepszej płacy. Liczba wolnych miejsc pracy na koniec pierwszego kwartału 2019 r. w jednostkach zatrudniających co najmniej 1 osobę wynosiła 142,5 tys. i była wyższa o 3,3 tys., tj. o 2,3\%, niż na koniec 2018 r. Na początku 2019 r. utworzono o 1,7\% więcej nowych miejsc pracy niż

10 Ibidem, s. 15.

11 Szerzej na ten temat: Barometr zawodów 2018, https://barometrzawodow.pl/ userfiles/Barometr/2018/Raport_polska_ok-min.pdf (dostęp: 13.10.2018). 
rok wcześniej. Najwięcej nowych miejsc pracy powstało na Mazowszu 57,4 tys. (21,9\%). Na drugim miejscu było województwo śląskie - 35,1 tys. $(13,4 \%)$, na trzecim natomiast lódzkie $-29,1$ tys. $(11,1 \%)^{12}$. Zatrudnianie cudzoziemców stało się więc popularnym rozwiązaniem. Uzupełniają oni braki, których nie dało się zapełnić polskimi pracownikami. Przedsiębiorca, zanim otrzyma pozwolenie na zatrudnienie cudzoziemca, musi przejść tzw. test rynku pracy, czyli udowodnić w odpowiednim urzędzie pracy, że nie mógł znaleźć polskiego pracownika na dane stanowisko. Badanie ankietowe przeprowadzone w 2018 r. przez polski związek pracodawców Business Centre Club we współpracy z Międzynarodową Organizacją do spraw Migracji (IOM) wśród przedsiębiorców będących członkami BCC wykazało, że ponad połowa $(54,5 \%)$ firm zatrudnia cudzoziemców ${ }^{13}$. Dodatkowo, ponad $2 / 3$ firm $(68,2 \%)$ jest zainteresowanych zatrudnieniem cudzoziemców na dłuższy okres (powyżej 9 miesięcy). Wszyscy ankietowani byli jednak zgodni co do jednego - brak polskich pracowników o wymaganych kwalifikacjach jest główną przyczyną decyzji polskich przedsiębiorców o zatrudnianiu cudzoziemców.

Podstawowym źródłem informacji cząstkowej na temat skali i struktury zatrudnienia cudzoziemców w Polsce są dane dostarczane przez Ministerstwo Pracy i Polityki Społecznej. Obejmują one kategorię cudzoziemców niemających swobody dostępu do rynku pracy w Polsce, a więc takich, którzy mogą świadczyć pracę na podstawie zezwoleń lub oświadczeń pracodawców o zamiarze powierzenia pracy cudzoziemcowi (od 1 stycznia $2018 \mathrm{r}$. jest to oświadczenie o powierzeniu wykonywania pracy cudzoziemcowi $)^{14}$. Zezwolenie na pracę to dokument pozwalający cudzoziemcowi na podjęcie legalnej pracy w Polsce pod warunkiem posiadania wizy lub zezwolenia na pobyt czasowy w celu wykonywania pracy.

W 2017 r. wydanych zostało prawie 236 tys. zezwoleń na pracę, co stanowiło w stosunku do 2016 r. wzrost o 85\%. W 2018 r. wydanych zostało ponad 328 tys. zezwoleń na pracę, co stanowiło w stosunku do $2017 \mathrm{r}$. wzrost o $40 \%$.

12 Szerzej na ten temat: Popyt na pracę w I kwartale 2019 roku, Główny Urząd Statystyczny, https://stat.gov.pl/obszary-tematyczne/rynek-pracy/popyt-na-prace/popyt-na-prace-w-pierwszym-kwartale-2019-roku,2,33.html (dostęp: 16.10.2019).

13 Zob. Business Centre Club, Międzynarodowa Organizacja do spraw Migracji (IOM), Zatrudnianie cudzoziemców a sytuacja na polskim rynku pracy, https://www. bcc.org.pl/wp-content/uploads/zatrudnianie-cudzoziemcow-a-sytuacja-na-polskim-rynku-pracy-22-03-2018.pdf (dostęp: 13.10.2018).

14 M. Piotrowski, A. Organiściak-Krzykowska, Zatrudnienie cudzoziemców na polskim rynku pracy - aspekty popytowe i strukturalne, „Studia Prawno-Ekonomiczne” 2016, vol. C, s. 321. 
Rysunek 2. Liczba wydanych zezwoleń na pracę w latach 2008-2018

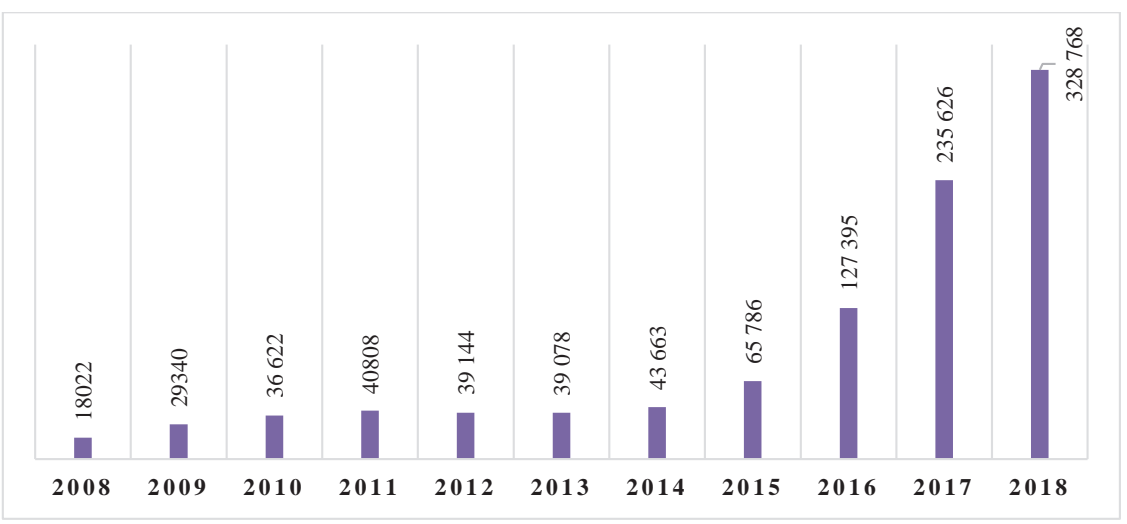

Źródło: opracowanie własne na podstawie danych Ministerstwa Rodziny, Pracy i Polityki Społecznej, http://www.mpips.gov.pl/.

Rysunek 3. Procentowy udział cudzoziemców zatrudnionych na podstawie zezwolenia na pracę (2018 r.)

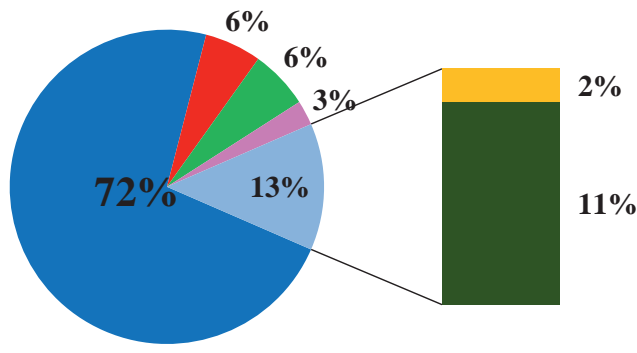

- UKRAINA
- BIALORUŚ
nEPAL
- INDIE
MOŁDAWIA
- POZOSTALE

Źródło: opracowano na podstawie danych Ministerstwa Pracy, Rodziny i Pomocy Społecznej, http://www.mpips.gov.pl/.

W 2017 r. dla obywateli Ukrainy wydanych zostało ok. 82\% (192 547) zezwoleń na pracę, za to w 2016 r. wydano ok. 83\% (106 223) zezwoleń dla obywateli tego kraju. Statystyki za 2018 r. pokazują zmniejszenie się znaczenia tej grupy cudzoziemców do $72 \%$, Obecnie wzrost wydawania zezwoleń na pracę dla Ukraińców jest mniej dynamiczny niż w przypadku państw takich jak: Białoruś, Mołdawia, Nepal czy Bangladesz, których udział w strukturze się zwiększa. Widocznie zmniejszyło się natomiast znaczenie migracji zarobkowej cudzoziemców z Dalekiego Wschodu - Chińczyków i Wietnamczyków. W 2012 r. zezwolenia wydane w związku z pracą obywateli Wietnamu i Chin stanowiły odpowiednio 5,9\% i 8,3\% wszystkich wydanych zezwoleń, w 2017 r. ich udział spadł poniżej $1 \%{ }^{15}$.

15 Ministerstwo Rodziny, Pracy i Polityki Społecznej, Departament Rynku Pracy, Informacja o zatrudnieniu cudzoziemców w Polsce, Warszawa 2018, s. 2. 
Rysunek 4. Oświadczenia o zamiarze powierzenia wykonywania pracy cudzoziemcowi (2008-2018)

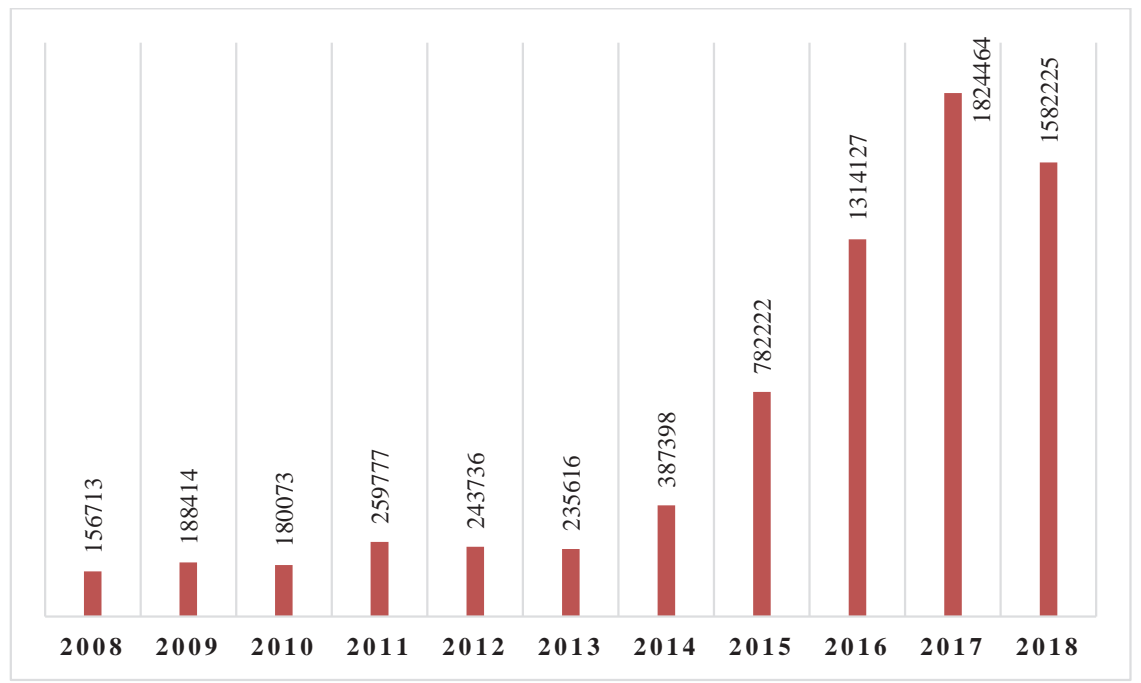

Źródło: opracowano na podstawie danych Ministerstwa Pracy, Rodziny i Pomocy Społecznej, http://www.mpips.gov.pl/.

W 2017 r. zarejestrowano ponad 1,8 mln oświadczeń o zamiarze powierzenia wykonywania pracy cudzoziemcowi dla ok. 1,1 mln cudzoziemców, co oznacza, że na jednego cudzoziemca przypadało średnio 1,7 oświadczenia. Liczbę pracodawców rejestrujących oświadczenia w 2017 r. można szacować na ok. 82 tys. Przeciętny pracodawca zarejestrował zatem 22 oświadczenia.

Rysunek 5. Procentowy udział cudzoziemców zatrudnionych na podstawie oświadczenia o zamiarze powierzenia wykonywania pracy cudzoziemcowi (2018 r.)

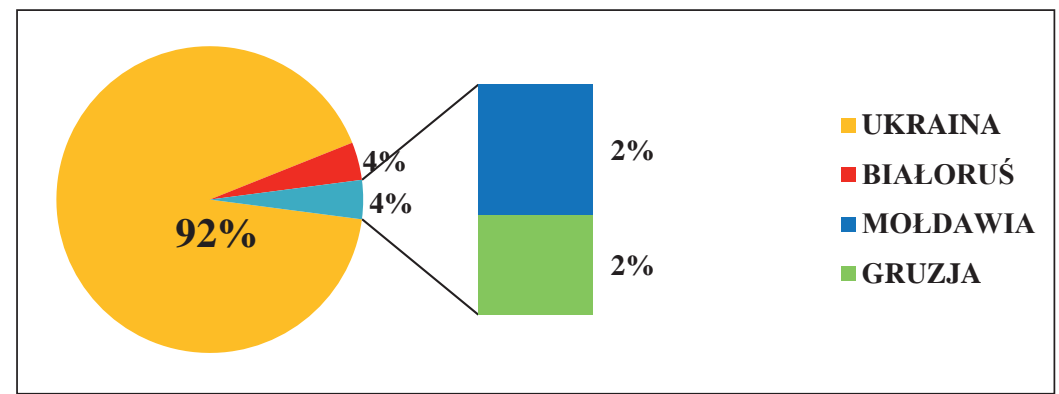

Źródło: opracowano na podstawie danych Ministerstwa Pracy, Rodziny i Pomocy Społecznej, http://www.mpips.gov.pl/. 


\subsection{Prawne aspekty zatrudnia cudzoziem ców w Polsce ${ }^{16}$}

Z punktu widzenia przyszłych polskich pracodawców zatrudnienie obywatela jednego z państw członkowskich Unii Europejskiej czy Europejskiego Obszaru Gospodarczego jest mniej skomplikowaną procedurą niż w przypadku chęci zatrudnienia obywatela $\mathrm{z}$ „państw trzecich”. Zgodnie bowiem Z art. 45 Traktatu o funkcjonowaniu Unii Europejskiej zagwarantowany został swobodny przepływ pracowników wewnątrz państw Unii Europejskiej $^{17}$. Przepisy te uprawniają do: poszukiwania pracy w innym państwie członkowskim, podejmowania tam pracy bez konieczności uzyskania pozwolenia na pracę, zamieszkania $\mathrm{w}$ innym państwie członkowskim ze względu na pracę, pozostania $\mathrm{w}$ innym państwie członkowskim nawet po zakończeniu stosunku pracy, o ile spełnione są warunki określone prawem UE, i traktowania na równi z obywatelami danego państwa członkowskiego w zakresie dostępu do zatrudnienia, warunków pracy oraz przywilejów socjalnych i podatkowych ${ }^{18}$. Stosownie do treści ustawy z dnia 14 lipca $2006 \mathrm{r}$. o wjeździe na terytorium Rzeczypospolitej Polskiej, pobycie oraz wyjeździe z tego terytorium obywateli państw członkowskich Unii Europejskiej i członków ich rodzin cudzoziemiec może wjechać na terytorium Polski na podstawie ważnego dokumentu tożsamości, a jeżeli podejmie pracę przysługuje mu prawo pobytu ${ }^{19}$. Jeżeli pobyt trwa jednak dłużej niż 3 miesiące, cudzoziemiec ma obowiązek zarejestrowania tego faktu u wojewody właściwego ze względu na miejsce swojego pobytu ${ }^{20}$. Kwestie związane z podjęciem pracy reguluje wspomniana we wstępie ustawa $\mathrm{z}$ dnia 20 kwietnia 2004 r. o promocji zatrudnienia i instytucjach rynku pracy ${ }^{21}$. W myśl jej art. 87 cudzoziemiec, który jest obywatelem państwa członkowskiego Unii Europejskiej, państwa Europejskiego Obszaru Gospodarczego, nienależącego do Unii Europejskiej lub państwa niebędącego stroną umowy o Europejskim Obszarze Gospodarczym, który może korzystać ze swobody przepływu osób na podstawie umowy zawartej przez to państwo ze Wspólnotą

16 Ustawa z dnia 26 lipca 1991 r. o podatku dochodowym od osób fizycznych (tekst jedn.: Dz.U. z 2018 r. poz. 1509 ze zm.) w art. 3 dzieli dodatkowo osoby na rezydentów oraz nierezydentów. Rezydentem jest osoba mająca nieograniczony obowiązek podatkowy, jeżeli jej miejsce zamieszkania znajduje się na terytorium Polski bez względu na miejsce położenia źródeł przychodów. Nierezydentem jest natomiast osoba niemająca miejsca zamieszania na terytorium Polski. W tej sytuacji podlega ona obowiązkowi podatkowemu tylko od dochodów (przychodów) osiąganych na terytorium Polski (ograniczony obowiązek podatkowy).

17 Traktat o funkcjonowaniu Unii Europejskiej, tekst skonsolidowany uwzględniający zmiany wprowadzone Traktatem z Lizbony, Dz.Urz. UE z 2016 r. C 202, s. 47.

18 A. Szczudło, Jak zatrudnić cudzoziemca z Unii Europejskiej?, https://www.prawowmodzie.pl/jak-zatrudnic-cudzoziemca-z-unii-europejskiej/ (dostęp: 20.08.2018).

19 Dz.U. z 2018 r. poz. 2094 ze zm; art. 9 ust. 1 oraz art. 16 ust. 1 pkt 1.

20 Art. 20 ust. 1 , art. 39 ust. 1.

21 Tekst jedn.: Dz.U. z 2019 r. poz. 1482 ze zm. 
Europejską i jej państwami członkowskimi, jest uprawniony do wykonywania pracy na terytorium Polski ${ }^{22}$. Obecnie każda osoba $\mathrm{z}$ wymienionym wyżej obywatelstwem może podjąć pracę zarobkową w Polsce bez konieczności uzyskiwania pozwolenia na pracę, co wiąże się z licznymi uproszczeniami w stosunku do cudzoziemców spoza tego obszaru.

Inaczej kształtuje się sytuacja cudzoziemców z państw trzecich, którzy chcą w Polsce podjąć zatrudnienie. Przepisy dotyczące obecnego zatrudniania tej kategorii cudzoziemców regulują przede wszystkim wspomniane wcześniej ustawa z dnia 20 kwietnia 2004 r. o promocji zatrudnienia i instytucjach rynku, ustawa $z$ dnia 12 grudnia 2013 r. o cudzoziemcach oraz rozporządzenia wykonawcze. Warunkiem powierzenia pracy cudzoziemcowi w Polsce jest uzyskanie odpowiedniego zezwolenia na pracę oraz jego legalny pobyt na terytorium Rzeczypospolitej Polskiej.

Pracodawca występuje o zezwolenie na pracę do właściwego wojewody. W przypadku gdy jest to zezwolenie typu „S” (zezwolenie na pracę sezonową), pracodawca występuje do właściwego starosty (powiatowego urzędu pracy). W przypadku jednolitego zezwolenia cudzoziemiec przebywający już legalnie na terytorium Polski występuje samodzielnie do właściwego wojewody. W polskim prawie występuje obecnie sześć zezwoleń na pracę. Od 1 stycznia 2018 r. praca krótkoterminowa może być wykonywana na podstawie oświadczenia o powierzeniu wykonywania pracy cudzoziemcowi (wcześniej było to oświadczenie o zamiarze powierzenia wykonywania pracy cudzoziemcowi) lub zezwolenia na pracę sezonową. Procedura oświadczeniowa pozwala obywatelom jednego z sześciu państw (Armenii, Białorusi, Gruzji, Mołdawii, Rosji i Ukrainy) wykonywać pracę w Polsce przez 6 miesięcy w okresie 12 następujących po sobie miesięcy bez konieczności uzyskania zezwolenia na pracę $\mathrm{w}$ zakresie, w jakim nie jest wydawane zezwolenie na pracę sezonową. Zezwolenie na pracę sezonową dotyczy obywateli wszystkich państw trzecich i jest wydawane na okres nie dłuższy niż 9 miesięcy w roku kalendarzowym ${ }^{23}$.

Istnieją kategorie cudzoziemców, którzy mogą wykonywać pracę bez zezwolenia bądź bez zezwolenia na pobyt czasowy i pracę. Ta sytuacja występuje najczęściej wówczas, gdy posiadają zezwolenie na pobyt stały lub rezydenta długoterminowego w Unii Europejskiej, są obywatelami państw członkowskich Unii Europejskiej lub są obywatelami państw Europejskiego Obszaru Gospodarczego itd. ${ }^{24}$ Dodatkowo, aby cudzoziemiec mógł legalnie wykonywać pracę w Polsce na podstawie zezwolenia, musi posiadać tzw. tytuł pobytowy. Cudzoziemcy są uprawnieni do wykonywania pracy jeżeli:

22 Art. 87 ust. 1 pkt 7-9. Jedynym takim państwem jest obecnie Szwajcaria.

23 Ministerstwo Rodziny, Pracy i Polityki Społecznej, Zatrudnianie cudzoziemców - zmiany od 1 stycznia 2018 r., https://www.mpips.gov.pl/praca/zatrudnienie-cudzoziemcow/ (dostęp: 5.08.2018).

24 Art. 87 ustawy o promocji zatrudnienia i instytucjach rynku pracy. 
- przybywają w Polsce na podstawie wizy (z wyjątkiem wizy wydanej w celu turystycznym, ochrony czasowej, przyjazdu ze względów humanitarnych);

- złożyli wniosek o udzielenie zezwolenia na pobyt czasowy lub stały;

- przybywają w Polsce na podstawie wizy wydanej przez inne państwo obszaru Schengen;

- przybywają w Polsce na podstawie dokumentu pobytowego wydanego przez inne państwo obszaru Schengen;

- przybywają w Polsce w ramach ruchu bezwizowego ${ }^{25}$.

Od 1 maja 2014 r. do ustawy o cudzoziemcach wprowadzono nowe rodzaje zezwoleń na pobyt czasowy. Poniżej opisano ogólne warunki otrzymania tego typu zezwoleń pod kątem wykonywania pracy i prowadzenia działalności gospodarczej $\mathrm{z}$ uwzględnieniem nowelizacji z dnia 12 stycznia $2018 \mathrm{r}^{26}$

Zezwolenia na pobyt czasowy udziela wojewoda właściwy ze względu na miejsce pobytu cudzoziemca w drodze decyzji, jeżeli zachodzą okoliczności uzasadniające zamieszkiwanie cudzoziemca na terytorium Rzeczypospolitej Polskiej przez okres dłuższy niż 3 miesiące. Zezwolenie udzielane jest maksymalnie na okres do 3 lat. Aby cudzoziemiec uzyskał zezwolenie na pobyt czasowy, musi przedstawić udokumentowane powody, dla których chce przebywać w Polsce, np. podjęcie lub kontynuacja pracy, praca w zawodzie wymagającym wysokich kwalifikacji, prowadzenie działalności gospodarczej itp. Cudzoziemiec, który uzyskał zezwolenie na pobyt czasowy na terytorium Polski, otrzymuje kartę pobytu - potwierdza ona tożsamość cudzoziemca oraz uprawnia go, wraz z dokumentem podróży, do wielokrotnego przekraczania granicy bez konieczności uzyskania wizy.

Najwięcej zezwoleń na pobyt czasowy otrzymali w przeciągu ostatnich dziesięciu lat obywatele Ukrainy. W 2017 r. wojewodowie wydali im 70268 pozwoleń. Dodatkowo już w pierwszym kwartale 2018 r. wydanych zostało 11806 pozwoleń na zamieszkanie lub pobyt czasowy dla obywateli tego państwa.

Zezwolenia związane z wykonywaniem pracy dzielimy na:

1) zezwolenia na pobyt czasowy i pracę (jednolite zezwolenie na pobyt i pracę);

2) zezwolenia na pobyt czasowy w celu wykonywania pracy w zawodzie wymagającym wysokich kwalifikacji;

25 Departament Rynku Pracy Ministerstwo Pracy, Rodziny i Polityki Społecznej, Zatrudnienie obywateli państw trzecich $w$ Polsce, https://psz.praca.gov.pl/dla-pracodawcow-i-przedsiebiorcow/zatrudnianie-cudzoziemcow/zatrudnienie-obywateli-panstw-trzecich-w-polsce (dostęp: 5.08.2018).

26 Ustawa z dnia 24 listopada 2017 r. o zmianie ustawy o cudzoziemcach oraz niektórych innych ustaw, Dz. U. z 2018 r. poz. 107. 
Rysunek 6. Liczba wydanych zezwoleń na pobyt czasowy w latach 2008-2018

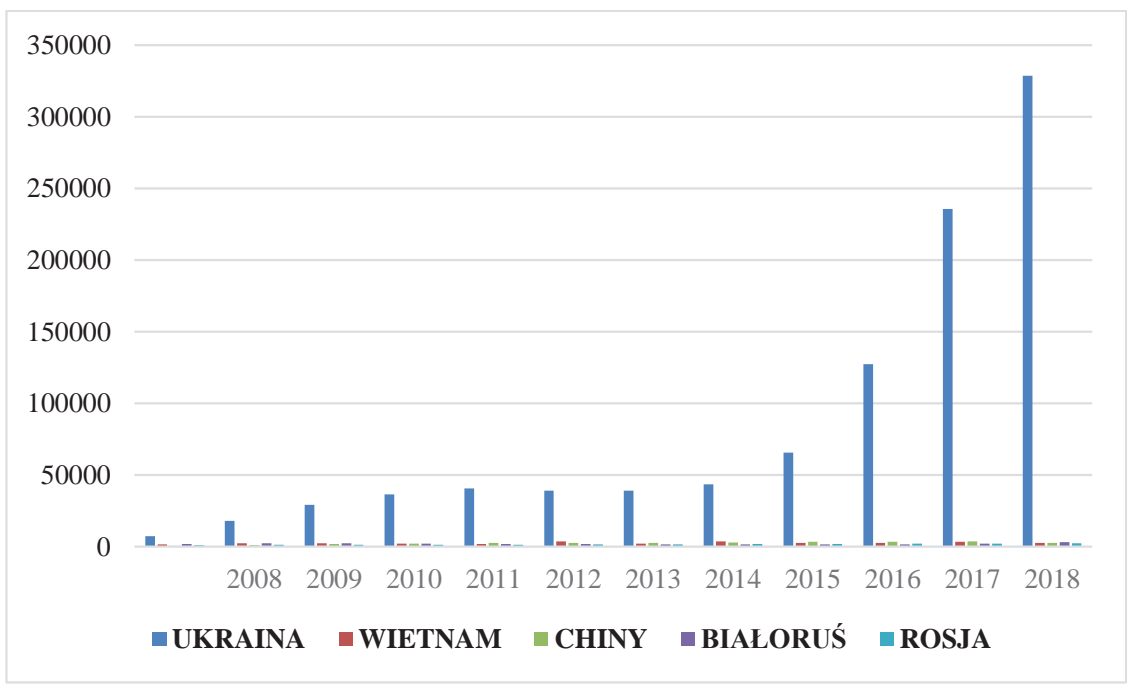

Źródło: Urząd do Spraw Cudzoziemców, https://udsc.gov.pl.

3) zezwolenia na pobyt czasowy w celu wykonywania pracy przez cudzoziemca delegowanego przez pracodawcę zagranicznego na terytorium Rzeczypospolitej Polskiej;

4) zezwolenia na pobyt czasowy ze względu na pracę sezonową;

5) zezwolenia na pobyt czasowy w celu prowadzenia działalności gospodarczej.

\subsubsection{Zezwolenie na pobyt czasowy i pracę}

Jednolite zezwolenie na pobyt czasowy i pracę to dokument umożliwiający cudzoziemcowi legalny pobyt w Polsce oraz wykonywanie pracy na rzecz konkretnego pracodawcy wskazanego $\mathrm{w}$ decyzji o udzieleniu zezwolenia. Podmiotem występującym o wydanie zezwolenia jest cudzoziemiec przebywający już legalnie na terytorium Polski. O wydanie takiego zezwolenia może ubiegać się cudzoziemiec: zamierzający podjąć lub kontynuować pracę lub zamierzający podjać lub kontynuować pracę polegającą na pełnieniu funkcji w zarządzie spółki akcyjnej lub spółki z o.o., której udziałów lub akcji ten cudzoziemiec nie posiada. Ważne jest, że cudzoziemcy prowadzący działalność gospodarczą delegowani do pracy przez pracodawcę mającego siedzibę poza granicami Polski oraz wykonujący pracę sezonową nie mogą ubiegać się o ten rodzaj zezwolenia. Jednolite zezwolenie uprawnia do wykonywania pracy na warunkach w nim określonych. Cudzoziemiec nie musi posiadać dodatkowego dokumentu uprawniającego go do wykonywania pracy $\mathrm{w}$ postaci zezwolenia na pracę. Uzyskania nowego zezwolenia wymaga się w sytuacji zmiany pracodawcy. Modyfikacji udzielonego zezwolenia wymagają natomiast okoliczności wykonywania pracy u inne- 
go użytkownika (praca tymczasowa) lub zmiana warunków określonych w posiadanym zezwoleniu ${ }^{27}$.

\subsubsection{Zezwolenie na pobyt czasowy w celu wykonywania pracy w zawodzie wymagającym wysokich kwalifikacji}

Ten rodzaj zezwolenia udzielany jest cudzoziemcowi, którego celem pobytu jest wykonywanie pracy w zawodzie wymagającym wysokich kwalifikacji, tj. ukończenia studiów wyższych albo posiadania co najmniej pięcioletniego doświadczenia zawodowego na poziomie porównywalnym $z$ poziomem kwalifikacji uzyskanych w wyniku ukończenia studiów wyższych, które są niezbędne do wykonywania tej pracy. Cudzoziemiec musi spełnić m.in. następujące wymogi: zawrzeć, na okres przynajmniej roku, umowę o pracę, umowę o pracę nakładczą, umowę cywilnoprawną, na podstawie której wykonuje pracę, świadczy usługi lub pozostaje w stosunku służbowym, posiadać formalne kwalifikacje oraz wyższe kwalifikacje zawodowe oraz zgodę właściwego organu na zajmowanie określonego stanowiska, wykonywanie zawodu lub prowadzenie innej działalności.

Po uzyskaniu tego typu zezwolenia cudzoziemiec może wykonywać pracę w Polsce na warunkach określonych w tym zezwoleniu bez konieczności posiadania dodatkowo zezwolenia na pracę. Jednak w okresie pierwszych dwóch lat pobytu cudzoziemca na podstawie tego zezwolenia nie może on rozpocząć wykonywania pracy u innego podmiotu niż określony w zezwoleniu, zmienić stanowiska, na jakim jest zatrudniony oraz nie można wypłacać mu wynagrodzenia niższego niż określone w zezwoleniu. Jeżeli po upływie dwóch lat cudzoziemiec będzie chciał zmienić powyższe warunki, powinien on wystąpić do wojewody właściwego ze względu na miejsce aktualnego pobytu o zamianę zezwolenia na pobyt czasowy. Zmiana zezwolenia nie jest wymagana w przypadku zmiany nazwy lub formy prawnej podmiotu powierzającego cudzoziemcowi wykonywanie pracy, a także w przypadku przejęcia zakładu pracy lub jego części przez inny podmiot ${ }^{28}$.

\subsubsection{Zezwolenie na pobyt czasowy w celu wykonywania pracy przez cudzoziemca delegowanego przez pracodawcę zagranicznego na terytorium Rzeczypospolitej Polskiej}

Zezwolenie na pobyt czasowy w celu wykonywania pracy przez cudzoziemca delegowanego przez pracodawcę zagranicznego do Polski jest udzielane cudzoziemcowi, jeżeli: posiada zezwolenie na pracę lub oświadczenie o zamiarze powierzenia mu pracy, posiada ubezpieczenie zdrowotne, źródło stabilnego i regularnego dochodu oraz zapewnione miejsce zamieszkania w Polsce. Zezwolenie to, w przeciwieństwie do dwóch poprzednich, nie uprawnia cudzoziemca do wykonywania pracy, dodatkowo powinien on mieć zezwolenie na pracę, chyba że nie jest ono wymagane ${ }^{29}$.

27 Art. 114-126 ustawy o cudzoziemcach.

28 Art. 127-138 ustawy o cudzoziemcach.

29 Art. 140-141 ustawy o cudzoziemcach. 


\subsubsection{Zezwolenie na pobyt czasowy ze względu na pracę sezonową}

Nowym typem zezwolenia na pobyt czasowy od 1 stycznia 2018 r. stało się zezwolenie na pobyt czasowy w związku z pracą sezonową. Zezwolenie to wydawane jest cudzoziemcowi, jeżeli spełnił on m.in. następujące warunki: wjechał na terytorium Rzeczypospolitej Polskiej na podstawie wizy wydanej w celu wykonywania pracy sezonowej albo w ramach ruchu bezwizowego, w związku z wnioskiem o wydanie zezwolenia na pracę sezonową, posiada zezwolenie na pracę sezonową lub przedłużenie zezwolenia na pracę sezonową, posiada źródło stabilnego i regularnego dochodu wystarczającego na pokrycie kosztów utrzymania oraz ma zapewnione zakwaterowanie na terytorium Rzeczypospolitej Polskiej. Zezwolenia na pobyt czasowy ze względu na pracę sezonową, w przeciwieństwie do poprzednio opisanych zezwoleń, udziela się na okres nie dłuższy niż 9 miesięcy od dnia pierwszego wjazdu w celu wykonywania pracy sezonowej. Dodatkowo zezwolenia tego udziela się nawet gdy okoliczności ubiegania się o to zezwolenie nie uzasadniają pobytu cudzoziemca na terytorium Rzeczypospolitej Polskiej przez okres dłuższy niż 3 miesiące. Zezwolenie to nie przyznaje samodzielnie cudzoziemcowi prawa dostępu do polskiego rynku pracy. Niesie to za sobą takie konsekwencje, że w każdym przypadku wykonywanie pracy sezonowej będzie wymagało posiadania zarówno ważnego zezwolenia na pracę sezonową, jak i ważnej podstawy do pobytu w celu wykonywania pracy zgodnie $\mathrm{z}$ tym zezwoleniem ${ }^{30}$.

\subsubsection{Zezwolenie na pobyt czasowy w celu prowadzenia działalności gospodarczej}

Problematyka podjęcia działalności gospodarczej przez cudzoziemca w Polsce została uregulowana w ustawie z dnia 6 marca 2018 r. o zasadach uczestnictwa przedsiębiorców zagranicznych i innych osób zagranicznych w obrocie gospodarczym na terytorium Rzeczypospolitej Polskiej ${ }^{31}$. Zgodnie $z$ jej treścią obywatele państw trzecich mają prawo do podejmowania i wykonywania działalności gospodarczej w formie spółek: komandytowej, komandytowo-akcyjnej, z ograniczoną odpowiedzialnością oraz akcyjnej. Ten rodzaj zezwolenia, zgodnie z ustawą o cudzoziemcach, zostanie udzielony cudzoziemcowi, którego celem jest: prowadzenie działalności gospodarczej podstawie przepisów obowiązujących w tym zakresie, pełnienie funkcji w zarządzie spółki z o.o. lub akcyjnej, której akcje lub udziały posiada, prowadzenie spraw spółki komandytowej lub komandytowo-akcyjnej w roli komplementariusza oraz działanie w charakterze prokurenta. W celu uzyskania tego rodzaju zezwolenia podmiot, który prowadzi działalność gospodarczą, powinien generować określony dochód, tworzyć miejsca pracy, posiadać odpowiednie środki lub prowadzić działania pozwalające na spełnienie tych warunków w przyszłości. Zezwolenie na pobyt czasowy

30 Art. 185a-185c ustawy o cudzoziemcach.

31 Dz.U. z 2019 r. poz. 1079 ze zm. 
w celu prowadzenia działalności gospodarczej uprawnia cudzoziemca jednocześnie do wykonywania pracy w tym charakterze. Podjęcie innej pracy wymaga uzyskania zezwolenia na pracę $e^{32}$.

\section{Konsekwencje regulacji związanych z podjęciem i wykonywaniem pracy przez cudzoziemców z państw trzecich}

Regulacje obowiązującej ustawy o cudzoziemcach, ustawy o promocji zatrudnienia i instytucjach rynku pracy oraz ich nowelizacje nie usunęły barier w dostępie do polskiego rynku pracy dla cudzoziemców. Dokonując analizy przepisów - przede wszystkim z zakresu wykonywania pracy czy prowadzenia działalności gospodarczej - wbrew ówczesnym założeniom legislatywy, należy stwierdzić, że wręcz wprowadziły one szereg utrudnień dla cudzoziemców. Według szacunków BCC (Business Center Club) już teraz potrzebujemy ok. 200 tys. imigrantów rocznie, żeby wyrównać straty na rynku pracy wynikające m.in. ze zmian demograficznych, obniżonego wieku emerytalnego czy z emigracji zarobkowej naszych rodaków ${ }^{33}$.

\subsection{Bariery w dostępie do polskiego rynku pracy}

Po pierwsze ważną barierą, o której należy wspomnieć, są trudności językowe. Zgodnie z obowiązującymi regulacjami wnioski w urzędach składane być mogą tylko w języku polskim. Powoduje to znaczne utrudnienie dla cudzoziemców, chcących załatwić sprawę w urzędzie, których nie zawsze stać na usługi tłumacza przysięgłego. Organy także wydają decyzje w języku polskim. W konsekwencji cudzoziemiec może nie w pełni zrozumieć ich treść lub pouczenie o przysługujących mu środkach odwoławczych. W związku z tym powinno zostać wprowadzone rozwiązanie, zgodnie z którym najważniejsze części decyzji administracyjnej byłyby przetłumaczone na język zrozumiały dla cudzoziemca. Po drugie, cudzoziemcy muszą również na odpowiednich etapach postępowania o legalizację pobytu czy pracy stawić się w urzędzie osobiście, np. po odbiór karty pobytu. Problem pojawia się $\mathrm{w}$ przypadku pobytu cudzoziemca w szpitalu lub za granicą, kiedy to nie może stawić się osobiście. Kwestię tę rozwiązałoby wprowadzenie regulacji umożliwiającej odbiór czy dopełnienie spraw w urzędzie przez upoważnioną osobę trzecią.

Kluczowe w likwidowaniu barier jest uproszczenie procedur i skrócenie czasu oczekiwania na uzyskanie zezwolenia na pobyt i pracę cudzoziemca. Obowiązujące od bieżącego roku zasady zatrudniania cudzoziemców

32 Art. 142-143a ustawy o cudzoziemcach.

33 Business Centre Club, Brak rak do pracy - usuńmy bariery w zatrudnianiu cudzoziemców, Warszawa 2017, s. 1, http://www.lubelskie.pl/file/2017/12/Za\%C5\%82.-Nr-4d.-Usu\%C5\%84my-bariery-w-zatrudnianiu-cudzoziemc\%C3\%B3w-BCC.pdf (dostęp: 2.08.2018). 
w wielu przypadkach wydłużyły i skomplikowały procedurę legalizacji pobytu i pracy. Wprowadzony został m.in. wymóg dostarczenia do urzędu dużej ilości załączników, co w przypadku wniosków papierowych obciąża zarówno cudzoziemca jak i urzędy, przez co zwiększa się czas oczekiwania na wydanie decyzji. Elektroniczna rejestracja wniosków w urzędach to dotychczas raczej przywilej aniżeli standard. W czasie oczekiwania na decyzję cudzoziemcy nie mają możliwości legalnego zatrudnienia, w konsekwencji zaczynają oni pracę "na czarno”. Artykuł $88 \mathrm{f}$ ust. 1 ustawy o promocji zatrudnienia i instytucjach rynku pracy szczegółowo reguluje treść zezwolenia na pracę. Należy zaznaczyć, że zgodnie z obowiązującym prawem cudzoziemiec otrzymuje zezwolenie na pracę u konkretnego pracodawcy i w okresie jego obowiązywania nie może pracodawcy zmienić. Uregulowanie to miało na celu przerzucenie ciężaru dokonywania formalności na pracodawcę, jednak z drugiej strony przypisuje ono cudzoziemca tylko i wyłącznie konkretnemu pracodawcy. W związku $\mathrm{z}$ tym zezwolenie na pracę powinno mniej szczegółowo określać warunki wykonywania pracy przez cudzoziemca decyzja nie powinna wskazywać konkretnego podmiotu powierzającego cudzoziemcowi wykonywanie pracy, ale np. obszar terytorialny. Dodatkowo decyzja powinna fakultatywnie (nie obligatoryjnie) zawierać również informacje określające stanowisko, na jakim cudzoziemiec ma wykonywać pracę, najniższe wynagrodzenie i minimalny wymiar czasu pracy. Również zezwolenie na pobyt czasowy i pracę (art. 118 ustawy o cudzoziemcach) powinno mniej szczegółowo określać warunki wykonywania pracy.

W przypadku, kiedy pracodawca wykorzystuje cudzoziemca, nie może on szybko zmienić pracy, gdyż musi uzyskać kolejne zezwolenie na pracę u nowego pracodawcy. Dotychczasowe rozwiązania powodują, że cudzoziemiec nie ma dostatecznego dostępu do rynku pracy i nie może swobodnie się na nim poruszać.

\subsection{Bariery w zatrudnianiu na polskim rynku pracy}

Jednym z większych problemów pracodawców, którzy chcą powierzyć wykonywanie pracy cudzoziemcom, jest brak kompleksowej i spójnej regulacji prawnej. W obrocie prawnym funkcjonuje kilka ustaw oraz rozporządzeń, a każde z nich reguluje inne kwestie związane z zatrudnianiem cudzoziemców. Widoczny od kilku lat rozwój polskiego rynku pracy, jeśli chodzi o zatrudnianie cudzoziemców oraz podążanie za jego aktualnymi potrzebami, uzasadnia częstą nowelizację przepisów. Ten proces doprowadził jednak do tego, że brakuje obecnie kompleksowej regulacji prawnej. Rozproszenie przepisów stanowi poważne utrudnienie dla pracodawców, którzy mogą nieświadomie nie przestrzegać przepisów lub stosować nieaktualne regulacje.

Należy również zlikwidować tzw. test rynku pracy. Gdy przedsiębiorca chce zatrudnić cudzoziemca, musi uzyskać z urzędu pracy informację 
o braku możliwości zaspokojenia potrzeb kadrowych na lokalnym rynku pracy. Urząd pracy ma obowiązek poszukać odpowiedniego kandydata wśród obywateli polskich, a dopiero po nieudanej próbie ich zalezienia przedsiębiorca otrzymuje zaświadczenie, które jest dołączane do wniosku o wydanie zezwolenia na pracę. W praktyce „test rynku pracy” ma charakter fikcyjny. Oferty często formułowane są tak, aby na proponowane stanowisko nie aplikował żaden polski kandydat (specyficzne języki obce, wąska specjalizacja, nieadekwatne wynagrodzenie). Jest to również strata czasu zarówno dla przedsiębiorcy, jak i urzędu pracy - efekt rekrutacji jest od początku z góry przesądzony, tzn. na dane stanowisko z pewnością nie zgłosi się żaden Polak. Alternatywą dla kłopotliwych "testów rynku pracy” mogłoby być wprowadzenie limitów wydawanych zezwoleń na pracę - cudzoziemców pracujących w Polsce jest niewielu i nie ma potrzeby dodatkowego ograniczania im dostępu do rynku pracy. Po trzecie, od 1 stycznia $2018 \mathrm{r}$. wraz $\mathrm{z}$ wnioskiem o wydanie zezwolenia na pracę lub $\mathrm{z}$ oświadczeniem o powierzeniu wykonywania pracy pracodawca ma obowiązek złożenia dodatkowego dokumentu, tj. oświadczenia o karalności, pod rygorem odpowiedzialności karnej. Ten dodatkowy wymóg postawiony podmiotom zlecającym pracę ograniczył możliwości powierzania pracy cudzoziemcom.

Artykuł 88j ustawy o promocji zatrudnienia i instytucjach rynku pracy wskazuje, przy jakich przestępstwach i wykroczeniach pracodawcy nie zostanie wydane zezwolenie na pracę. Informacje o skazaniu za przestępstwo zamieszczane są w Krajowy Rejestrze Karnym, przy czym w rejestrze tym nie ujawnia się wyroków skazujących za wykroczenia (chyba że orzeczono za nie karę aresztu). W związku z tym to na pracodawcy ciąży obowiązek udowodnienia, że nie był on skazany za wymienione $\mathrm{w}$ art. $88 \mathrm{j}$ przestępstwa i wykroczenia. Co więcej, autorem oświadczenia nie może być pełnomocnik. Stwarza to szczególne utrudnienia np. w przypadku, gdy pracodawca przebywa $z$ reguły za granicą. Oświadczenie o karalności powinno być wypełnione osobno do każdego wniosku dotyczącego danej osoby i jest to szczególnie problematyczne w przypadku pracodawców zatrudniających dużą liczbę pracowników. Biurokracja jest znaczącym utrudnieniem, które powoduje opóźnienia w gromadzeniu dokumentacji niezbędnej do uzyskania zezwolenia na pracę lub oświadczenia o zamiarze powierzenia pracy.

\subsection{Jednolite zezwolenie na pobyt i pracę - analiza sytuacji osób prowadzących działalność gospodarczą}

W założeniach obecnie obowiązującej ustawy o cudzoziemcach pojawiła się propozycja przyznania jednego zezwolenia - zarówno na pobyt, jak i na pracę. Oznacza to, że cudzoziemiec w ramach jednej procedury może zalegalizować zarówno swój pobyt, jak i wykonywanie pracy. Rozwiązanie to miało zmniejszyć problemy związane z licznymi czynnościami i wymogami stawianymi pracodawcom i ich przyszłym pracownikom, uproszczenie 
procedury powinno zaś było przyczynić się do sprawniejszego uzyskiwania zatrudnienia przez cudzoziemców, a co za tym idzie do ich szybszego uniezależniania się od pomocy państwa. Czy koncepcja połączenia dwóch odrębnych postępowań okazała się jednak trafna i odpowiednia dla każdej grupy cudzoziemców chcących wykonywać pracę w Polsce?

Patrząc z perspektywy osób prowadzących działalność gospodarczą, które chcą ubiegać się tylko o zezwolenie na pracę, a nie zezwolenie na pobyt czasowy, nie można tak stwierdzić. Spróbujmy wyobrazić sobie, że cudzoziemiec jest mniejszościowym udziałowcem spółki sp. z o.o., co jest przecież zgodne z prawem, a z powodu krótkiego okresu pobytu w Polsce nie potrzebuje zezwolenia na pobyt czasowy. Nie może jednak obejść się bez zezwolenie na wykonywanie pracy, jeśli zostałby mianowany członkiem zarządu tej spółki. Ustawa nie pozwala mu na takie ekonomiczne oraz często występujące $\mathrm{w}$ praktyce rozwiązanie. Taka osoba dodatkowo powinna mieć naturalne prawo do odpłatnego pełnienia funkcji w zarządzie spółki, której jest udziałowcem. Sprawa wygląda analogicznie w przypadku posiadania akcji przez akcjonariuszy spółki akcyjnej. Nieuchronną konsekwencją jednolitego zezwolenia jest fakt, że cudzoziemiec nie może ubiegać się o zezwolenie na pracę w zawodzie wymagającym wysokich kwalifikacji w swojej własnej spółce. Będąc udziałowcem lub posiadając akcje spółki, dana osoba nie zawsze przebywa na terytorium Polski, w związku z tym automatycznie nie spełnia kryteriów do przedłużenia jednolitego zezwolenia albo do starania się w przyszłości o zezwolenie na pobyt stały, po zasięgnięciu opinii wojewody, Straży Granicznej i Urzędu ds. Cudzoziemców.

W praktyce międzynarodowej nie ma podobnych przepisów, które wymagają zezwoleń na pobyt dla nierezydentów kraju, w którym pełniona jest funkcja członka zarządu w spółce, np. dyrektora. W społeczeństwie globalnym ludzie prowadzący interesy nie powinni być ograniczani w taki sposób. Nie ma przeciwwskazań, aby dyrektorem polskiej spółki był Niemiec czy Francuz - nie należy więc dyskryminować obywateli państw trzecich, którzy i tak mają prawo do posiadania udziałów w spółce. Skłonność do inwestycji osób z zewnątrz posiadających odpowiedni kapitał doprowadzi w długim okresie do rozwoju potencjału gospodarczego Polski. Powyższa analiza jasno dowodzi, że $\mathrm{w}$ zderzeniu z rzeczywistością nowe regulacje mają skutki przeciwne do zamierzonych przez ustawodawcę.

\section{Zakończenie}

W 2018 r. można było zaobserwować wzrostową tendencję zatrudniania cudzoziemców w Polsce. Wydano rekordową liczbę zezwoleń na pracę i tym samym zarejestrowano rekordową ilość oświadczeń o zamiarze powierzenia wykonywania pracy cudzoziemcowi. 
W dalszym ciągu utrzymuje się dominujący udział Ukraińców wśród cudzoziemców podejmujących pracę w Polsce. Trudno tak naprawdę ocenić, ilu obywateli Ukrainy obecnie pracuje w naszym kraju. Szacuje się, że liczba pracujących cudzoziemców jest dwukrotnie większa, niż to wynika ze statystyk, ponieważ większość z nich pracuje „na czarno”. Ze sprawozdania Państwowej Inspekcji Pracy wynika, że inspektorzy pracy przeprowadzili w 2018 r. 7817 kontroli legalności zatrudnienia i wykonywania pracy przez cudzoziemców (o 9\% więcej niż w 2017 r. i o 84\% więcej niż w 2016 r.). W toku kontroli wykazano powierzenie nielegalnej pracy 4562 cudzoziemcom, w tym 4560 cudzoziemcom będącym obywatelami państw trzecich. Największą grupę nielegalnie zatrudnionych cudzoziemców stanowili obywatele Ukrainy, co stanowi $86 \%$ ogółu cudzoziemców, którym powierzono nielegalne wykonywanie pracy $^{34}$. Wielu polskich przedsiębiorców widzi w tej sytuacji zagrożenie dla polskiego rynku pracy, spowodowane konkurencją $\mathrm{w}$ dostępie do miejsc pracy oraz dumpingiem płac. Ukraińcy, pracując bez umowy, godzą się często na niższe stawki, dlatego są też chętniej zatrudniani. W konsekwencji legalnie działające firmy nie są w stanie konkurować z przedsiębiorstwami zatrudniającymi pracowników „na czarno”. Największą popularnością wśród cudzoziemców cieszą się takie branże, jak budownictwo, przemysł, handel, gastronomia czy pomoc domowa. W przyszłości trend ten może jednak rozszerzyć się na inne sektory gospodarki.

Pomimo że niektórzy cudzoziemcy nastawieni są na szybki powrót do kraju macierzystego z zarobionymi pieniędzmi, to wciąż ich obecność na polskim rynku pracy przynosi znaczące korzyści - wypełniają luki w miejscach pracy, płacą podatki i składki, a tym samym poprawiają sytuację finansów publicznych. Wielu z nich świadczy usługi opieki i pomocy w pracach domowych, ułatwiając zwiększenie podaży pracy polskim pracownikom ${ }^{35}$. Wraz z otwarciem w Europie Zachodniej rynków pracy dla cudzoziemców mogą oni zacząć wybierać kraje, w których oferowane są lepsze zarobki i warunki pracy. Dlatego też polska polityka imigracyjna powinna zmierzać do wprowadzenia jak największych ułatwień związanych z pracą i pobytem, aby ograniczyć odpływ cudzoziemców do Europy Zachodniej.

Aby zatrzymać rosnącą liczbę cudzoziemców pracujących „na czarno”, lepiej kontrolować legalną imigrację zarobkową i prowadzić jak najkorzystniejszą politykę imigracyjną, polski ustawodawca powinien po pierwsze ułatwić procedury rejestracji legalizacji pracy w Polsce. Kolejki, długi czas

34 Państwowa Inspekcja Pracy, Sprawozdanie z działalności państwowej Inspekcji Pracy w 2018 roku, https://www.pip.gov.pl/pl/f/v/211637/Sprawozdanie\%202018\%20r. (dostęp: 3.08.2019), s. 118.

35 R. Trzeciakowski, K. Wąsowska, Analiza 7/2018: Potrzebujemy imigrantów. Jak zatrzymać ukrainskich pracowników w Polsce?, lipiec 2018, https://for.org.pl/ $\mathrm{pl} / \mathrm{a} / 6100$,analiza-7/2018-potrzebujmy-imigrantow-jak-zatrzymac-ukrainskich-pracownikow-w-polsce (dostęp: 9.08.2018). 
oczekiwania na decyzje, biurokracja, brak znajomości języka polskiego przez cudzoziemców, konieczność ich osobistego stawiennictwa w urzędach są tylko kilkoma powodami, dla których większość cudzoziemców wybiera pracę w szarej strefie.

Po drugie, przepisy regulujące zatrudnienie cudzoziemców są bardzo zróżnicowane i rozsiane po kilku aktach prawnych. Cudzoziemiec, który chce zapoznać się z prawnym aspektem swojego legalnego zatrudnienia, musi przedrzeć się przez ogromną ilość przepisów i odniesień, co wymaga dużej ilości czasu oraz wiedzy prawnej. W związku z tym powinien powstać jednolity akt prawny, który będzie zawierał zebrane w całość kwestie dotyczące zatrudnienia cudzoziemców w Polsce.

Po trzecie, należy zwiększyć kontrolę procesu zatrudniania i przebywania cudzoziemców w Polsce. Dwie podstawowe instytucje opracowujące takie dane (Główny Urząd Statystyczny oraz Urząd do Sprawy Cudzoziemców) w odmienny sposób gromadzą dane dotyczące migrantów i inaczej przedstawiają informacje dotyczące cudzoziemców przebywających i pracujących w Polsce. Powinno się więc albo ujednolicić oba te systemy, albo stworzyć jeden system, który będzie zawierał wszystkie informacje na temat migracji cudzoziemców w Polsce.

Po czwarte, trzeba wprowadzić kompleksowe instrumenty zwalczania nielegalnego zatrudnienia cudzoziemców, z bardziej aktywnym udziałem wszystkich organów kontrolnych i innych instytucji, których działania są związane z problematyką nadużyć na rynku pracy.

Należy założyć, iż w przyszłości strumień imigracji do Polski, szczególnie z tzw. krajów trzecich, będzie się poszerzał. Prawdopodobnie nie staniemy się takim krajem imigracyjnym jak Wielka Brytania czy Niemcy, ale jednak liczba cudzoziemców zamieszkujących w Polsce będzie zdecydowanie większa niż obecnie ${ }^{36}$. Podsumowując, trzeba pomyśleć o tym problemie perspektywicznie, na większą skalę i w przyszłości podeprzeć się rozwiązaniem powszechnie stosowanym w wysokorozwiniętych krajach, które dzięki zatrudnianiu cudzoziemców podtrzymują swój rozwój gospodarczy.

\section{Bibliografia}

Barometr zawodów 2018, https://barometrzawodow.pl/userfiles/Barometr/2018/ Raport_polska_ok-min.pdf.

Business Centre Club, Brak rąk do pracy - usuńmy bariery w zatrudnianiu cudzoziemców, Warszawa 2017, http://www.lubelskie.pl/file/2017/12/Za\%C5\%82.-Nr-4d.-Usu\%C5\%84my-bariery-w-zatrudnianiu-cudzoziemc\%C3\%B3w-BCC.pdf.

Business Centre Club, Międzynarodowa Organizacja do spraw Migracji (IOM), Zatrudnianie cudzoziemców a sytuacja na polskim rynku pracy, https://www.

36 P. Dąbrowski, M. Duszczyk, Wprowadzenie [w:] Przestrzeganie praw cudzoziemców w Polsce, Warszawa 2012, s. 5. 
bcc.org.pl/wp-content/uploads/zatrudnianie-cudzoziemcow-a-sytuacja-na-polskim-rynku-pracy-22-03-2018.pdf.

Dąbrowski P., Duszczyk M., Wprowadzenie [w:] Przestrzeganie praw cudzoziemców w Polsce, Warszawa 2012.

Departament Rynku Pracy Ministerstwo Pracy, Rodziny i Polityki Społecznej, Zatrudnienie obywateli państw trzecich w Polsce, https://psz.praca.gov.pl/dla-pracodawcow-i-przedsiebiorcow/zatrudnianie-cudzoziemcow/zatrudnienie-obywateli-panstw-trzecich-w-polsce.

Główny Urząd Statystyczny, Popyt na pracę w I kwartale 2018 roku, https://stat. gov.pl/obszary-tematyczne/rynek-pracy/popyt-na-prace/popyt-na-prace-w-pierwszym-kwartale-2018-roku,2,29.html.

Główny Urząd Statystyczny, Wyniki Narodowego Spisu Powszechnego Ludności i Mieszkań 2011 Podstawowe informacje o sytuacji demograficzno-społecznej ludności Polski oraz zasobach mieszkaniowych, https://stat.gov.pl/cps/rde/xbcr/ gus/lu_nps2011_wyniki_nsp2011_22032012.pdf.

Karakała A., Pojęcie cudzoziemca i ogólna charakterystyka unormowań dotyczacych jego statusu [w:] Prawo administracyjne materialne, Z. Duniewska, B. JaworskaDębska, M. Stahl (red.), Warszawa 2014.

Ministerstwo Rodziny, Pracy i Polityki Społecznej, Departament Rynku Pracy, Informacja o zatrudnieniu cudzoziemców w Polsce, Warszawa 2018.

Ministerstwo Rodziny, Pracy i Polityki Społecznej, Zatrudnianie cudzoziemców zmiany od 1 stycznia 2018 r., https://www.mpips.gov.pl/praca/zatrudnieniecudzoziemcow/.

Państwowa Inspekcja Pracy, Sprawozdanie z działalności państwowej Inspekcji Pracy w 2018 roku, https://www.pip.gov.pl/pl/f/v/211637/Sprawozdanie\%20 2018\%20r.

Piotrowski M., Organiściak-Krzykowska A., Zatrudnienie cudzoziemców na polskim rynku pracy - aspekty popytowe i strukturalne, „Studia Prawno-Ekonomiczne" 2016, vol. C.

Popyt na pracę w I kwartale 2019 roku, Główny Urząd Statystyczny, https://stat. gov.pl/obszary-tematyczne/rynek-pracy/popyt-na-prace/popyt-na-prace-w-pierwszym-kwartale-2019-roku,2,33.html.

Samoraj B., Rynek pracy a cudzoziemcy w Polsce. Garść refleksji [w:] Polityka społeczna. Badania, dydaktyka, rozwój, A. Rączaszek (red.), Katowice 2008.

Szczepaniak M., Cudzoziemcy w Polsce - zjawiska i charakterystyka kulturowa wybranych grup [w:] Cudzoziemcy w Polsce. Podręcznik dla funkcjonariuszy publicznych, E. Ostaszewska-Żuk (red.), Warszawa 2016.

Szczudło A., Jak zatrudnić cudzoziemca z Unii Europejskiej?, https://www.prawowmodzie.pl/jak-zatrudnic-cudzoziemca-z-unii-europejskiej/.

Trzeciakowski R., Wąsowska K., Analiza 7/2018: Potrzebujemy imigrantów. Jak zatrzymać ukrainskich pracowników w Polsce?, lipiec 2018, https://for.org.pl/ $\mathrm{pl} / \mathrm{a} / 6100$,analiza-7/2018-potrzebujmy-imigrantow-jak-zatrzymac-ukrainskich-pracownikow-w-polsce. 
Traktat o funkcjonowaniu Unii Europejskiej - tekst skonsolidowany uwzględniający zmiany wprowadzone Traktatem z Lizbony, Dz.Urz. UE z 2016 r. C 202, s. 47.

Ustawa z dnia 12 grudnia 2013 r. o cudzoziemcach, tekst jedn.: Dz. U. z 2018 r. poz. 2094 ze zm.

Ustawa z dnia 13 czerwca 2003 r. o udzielaniu cudzoziemcom ochrony na terytorium Rzeczypospolitej Polskiej, tekst jedn.: Dz.U. z 2019 r. poz. 1666 ze zm.

Ustawa z dnia 14 lipca 2006 r. o wjeździe na terytorium Rzeczypospolitej Polskiej, pobycie oraz wyjeździe z tego terytorium obywateli państw członkowskich Unii Europejskiej i członków ich rodzin, tekst jedn.: Dz.U. z 2019 r. poz. 293 ze zm.

Ustawa z dnia 20 kwietnia 2004 r. o promocji zatrudnienia i instytucjach rynku pracy, tekst jedn.: Dz. U. z 2019 r. poz. 1482 ze zm.

Ustawa z dnia 6 marca 2018 r. o zasadach uczestnictwa przedsiębiorców zagranicznych i innych osób zagranicznych w obrocie gospodarczym na terytorium Rzeczypospolitej Polskiej, tekst jedn.: Dz. U. z 2019 r. poz. 1079 ze zm.

\section{Streszczenie}

Artykuł dotyczy ustawodawstwa regulującego ubieganie się przez cudzoziemców z państw spoza Unii Europejskiej (z państw trzecich) o zezwolenie na wykonywanie pracy w Polsce. Jego celem jest ustalenie, czy zadania, które postawił przed sobą ustawodawca, tj. ujednolicenie i uproszczenie przepisów oraz usprawnienie wydawania cudzoziemcom zezwoleń na pracę zarobkową, zostały zrealizowane. W związku z tym opisano ułatwienia, ale i administracyjno-prawne bariery, na jakie napotykają cudzoziemcy z państw trzecich, którzy chcą pracować w Polsce. Przeanalizowano m.in. procedury uzyskiwania przez cudzoziemców z państw trzecich jednolitego zezwolenia na pobyt i pracę, zezwolenia na pobyt czasowy ze względu na pracę sezonową oraz zezwolenia na pobyt czasowy w celu prowadzenia działalności gospodarczej.

Słowa kluczowe: dostęp do zatrudnienia, cudzoziemcy, zezwolenie na pobyt i pracę

\section{Legal Aspects of Employment of Foreign Nationals from Non-EU Countries in Poland}

Abstract

The article concerns legislation regulating the application by foreigners from countries outside of the European Union (third countries) for the work permit in Poland. The aim is to establish whether the objectives set by the legislator, i.e. legislative harmonisation and simplification as well making the process of issuing permits for remunerated work to foreigners, have been attained. Consequently, this study defines facilitations yet mainly administrative-legal obstacles faced by non-EU foreign nationals wishing to work in Poland. The article features an analysis of, inter alia, procedures for obtaining by non-EU foreigners a single stay and work permit, a temporary stay permit related to seasonal work as well as temporary stay permit related to economic operation.

Keywords: access to employment, foreigners, stay and work permit 